\title{
Basic Fibroblast Growth Factor Autocrine Loop Controls Human Osteosarcoma Phenotyping and Differentiation
}

\author{
Maria Bodo*, ${ }^{1}$ Cinzia Lilli*, ${ }^{1}$ Catia Bellucci, ${ }^{1}$ Paolo Carinci, ${ }^{2}$ Mario Calvitti, ${ }^{1}$ Furio Pezzetti, ${ }^{2}$ Giordano \\ Stabellini, ${ }^{3}$ Silvia Bellocchio, ${ }^{1}$ Chiara Balducci, ${ }^{1}$ Francesco Carinci, ${ }^{4}$ and Tiziano Baroni ${ }^{1}$ \\ ${ }^{1}$ Sezione di Istologia, Facoltà di Medicina, Università di Perugia \\ ${ }^{2}$ Istituto di Istologia ed Embriologia generale, Università degli Studi di Bologna \\ ${ }^{3}$ Dipartimento di Anatomia Umana, Università Statale di Milano \\ ${ }^{4}$ Cattedra di Chirurgia Maxillo-Facciale, Università di Ferrara, Italy
}

Accepted June 19, 2002

\begin{abstract}
Background: We focused on the phenotype of nonmineralizing MG63 and mineralizing TE85 human osteosarcoma cells and investigated the role of bFGF in modulating their differentiative responses. Basic FGF expression and bFGF effects on osteocalcin, runt-related transcription factor-2 (RUNX2), matrix molecular production and bFGF receptors, were evaluated.

Materials and Methods: Osteocalcin and RUNX2 gene expression were studied by RT-PCR analysis. We evaluated cell proliferation by DNA content and performed differentiation studies on glycosaminoglican (GAG), collagen and proteoglican (PG) synthesis by using radiolabelled precursors and Northern blotting. BFGF receptors were quantified by bFGF receptor binding assay.

Results: Osteocalcin is expressed in MG63 and TE65. RUNX2 RNA is differentially spliced in the two cell lines.
\end{abstract}

BFGF elicits the effects of differentially splicing RUNX2. Proliferation, GAG synthesis, bFGF and proteoglycan mRNA expression, high and low affinity bFGF receptors, were more marked in MG63 and differently affected by bFGF. Procollagen expression and alkaline phosphatase activity were significantly reduced. BFGF increased TE85 cell proliferation and reduced TE85 procollagen and osteocalcin production.

Conclusions: The different splice variants in RUNX2 gene in the two cell lines might be related to their different phenotypes. The less differentiated stage of MG63 could also be related to bFGF over-production and more bFGF receptors. The consequent increase in bFGF-bFGF receptor binding could explain the bFGF differentiative effects on MG63. We suggest an autocrine role of bFGF endogenous release in controlling the different osteosarcoma phenotypes.

\section{Introduction}

Tumour cell differentiation correlates with the prognosis $(1,2)$ and growth factor autocrine loops play an important role in malignant bone tumour development $(3,4)$.

Normal bone development and remodelling involves a well orchestrated spatial and temporal production of various ECM components such as type I collagen, glycosaminoglycans (GAG), proteoglycans (PG), and growth factors $(5,6)$. All these macromolecules contribute to render the matrix competent for mineralization, which is essential for complete expression of the osteoblast phenotype.

Abnormal production of growth factors affects extracellular matrix (ECM) bone metabolism $(7,8)$. The basic fibroblast growth factor (bFGF) acts as a potent modulator of bone cell proliferation and differentiation $(9,10)$. Recent evidence suggests bFGF receptor mutations and bFGF-induced changes in ECM production are linked to several bone

Address correspondence and reprint requests to: Maria Bodo, Sez. Istologia, Via del Giochetto 06126, Università degli Studi di Perugia, Italy. Fax: (39) 075 5857434, e-mail: bodo@unipg.it *These authors contributed equally to the project. diseases characterized by abnormal osteogenesis (11-13).

In the light of these observations, we wondered whether the bFGF pathway is involved in driving osteosarcoma cells towards a more or less differentiated osteoblast phenotype. We examined bFGF expression and the effects of bFGF on cell growth and differentiation in two widely used human osteosarcoma cell lines, MG63 and TE85. In culture, both lines express characteristic features of osteoblast lineage, but MG63 is considered a non-mineralizing cell line, while TE85 is a mineralizing cell line (14-16). To evaluate their differentiation states and the effects of bFGF, we studied markers of osteoblast differentiation such as alkaline phosphatase (ALP), osteocalcin and runt-related transcription factor-2 (RUNX2) gene expression. The RUNX2 gene has different transcripts, generated from alternative splicing from RUNX2 transcription start sites under the control of two promoters, P1 and P2 (17). There are two major RNA species that are transcribed from these two promoters and encode two principal isoforms with different $\mathrm{N}$ termini (P1/MASNS and P2/MRIPV) (18). P2/MRIPV appears to be expressed more constitutively and at an early time 
point in mesenchimal pluripotent precursor cells, while PI/MASNS isoform is expressed late when the precursor cells become committed to the osteoblast phenotype (19). Few data are available on the biological effects of the RUNX2 gene. In this study, we observed for the first time a different bFGF modulation of RUNX2 isoforms in MG63 and TE85 cells.

Finally, cell proliferation, GAG synthesis, the expression of type I procollagen, and several PG which are involved in osteoblast matrix composition were evaluated, and the results were related to bFGF receptor number in the two cell lines.

\section{Materials and Methods Cell Cultures}

Human MG63 and TE85 osteosarcoma cell lines were obtained from the American Type Cell Collection, Rockville, MD and maintained in Eagle's Minimum Essential medium (MEM), supplemented with $10 \%(\mathrm{v} / \mathrm{v})$ fetal calf serum (FCS), non-essential aminoacids (Gibco BRL), penicillin G (100 U/ml), streptomycin sulphate $(100 \mu \mathrm{g} / \mathrm{ml})$, and amphotericin B $(2.5 \mu \mathrm{g} / \mathrm{ml})$ (Sigma). The cells were routinely subcultured once a week. For experiments, MG63 and TE85 osteosarcoma cells were seeded at $80 \times 10^{3}$ cells/well (Nunc Multiwell diskes, $9.9 \mathrm{~cm}^{2}$ ), maintained for $96 \mathrm{~h}$ in MEM $+10 \%$ FCS, then treated for $24 \mathrm{~h}$ in MEM $+0.5 \%$ FCS with or without bFGF (20 ng/ml).

\section{Alkaline Phosphatase Activity}

After maintenance in vitro, cells were rinsed with saline and scraped in $10 \mathrm{mM}$ Tris- $\mathrm{HCl}(\mathrm{pH} 7.6)$ containing Triton X-100 and $0.5 \mathrm{mM} \mathrm{MgCl}$, sonicated, and stored at $-20^{\circ} \mathrm{C}$. Alkaline phosphatase activity (ALP) was determined in cell lysate by measuring the release of $p$-nitrophenol from disodium p-nitrophenyl phosphate (PNPP) (20). An aliquot of cell lysate was added to the substrate solution containing 10mM PNPP in $100 \mathrm{mM}$ diethanolamine buffer ( $\mathrm{pH}$ 10.5) with $0.5 \mathrm{mM}$ $\mathrm{MgCl}_{2}$. After incubation at $37^{\circ} \mathrm{C}$ for $\mathrm{lh}$, the reaction was stopped by adding $1 \mathrm{ml} 0.2 \mathrm{M} \mathrm{NaOH}$. Absorbance was determined at $410 \mathrm{~nm}$. Results are expressed as U/ $\mu$ g DNA. One unit is defined as the amount of enzyme required to hydrolyse $1 \mu$ mole of PNPP/min.

\section{DNA Assay and Cell Number}

DNA content was measured in cells homogenized with Ultra-Turrax (IKA-Werk) in phosphate saline buffer (PBS) pH 7.4 (21). Aliquots of homogenate were mixed with PBS containing bisbenzimide (Hoechst 33258, Sigma) to a final concentration of $1 \mu \mathrm{g} / \mathrm{ml}$. The fluorescence was measured by a fluorimetric method, and DNA content was expressed as $\mu \mathrm{g}$ DNA/ml of cell homogenate. To determine cell number, MG63 and TE85 were harvested with PBS, sedimented by centrifugation at $2,000 \mathrm{rpm}$, and resuspended in $1 \mathrm{ml}$ of medium. Tripan Blue was added to the cell suspension to obtain a final concentration of $2 \mathrm{mg} / \mathrm{ml}$. Cells were incubated for $5 \mathrm{~min}$. at room temperature and the number of stained cells determined by counting with Burker's camera.

\section{Detection of RUNX2 and Osteocalcin by RT-PCR Analysis}

MG63 and TE85 cells were treated as above and total RNA was isolated by lysing the cells with TRIzol reagent (Invitrogen s.r.l., Italy). The RNA was treated immediately with DNAse I (Invitrogen, Italy), and the integrity of the treated RNA was examined by detection of ribosomal RNA bands (28S and 18S) in ethidium bromide stained agarose gels. The RNA was quantified by reading the optical density at $260 \mathrm{~nm}$. One to two micrograms of total RNA were reverse transcribed for $1 \mathrm{~h}$ at $37^{\circ} \mathrm{C}$. Reverse transcription (RT) was performed in a final volume of $50 \mu \mathrm{l}$ containing $50 \mathrm{mM}$ Tris- $\mathrm{HCl}\left(\mathrm{pH} 8.3\right.$ at $\left.25^{\circ} \mathrm{C}\right)$, $3 \mathrm{mM} \mathrm{MgCl}$, $75 \mathrm{mM} \mathrm{KCl}, 10 \mathrm{mM}$ DTT, $0.5 \mathrm{mM}$ each deoxynucleotide triphosphate (dNTP), 40 units/tube RNaseOUT (Invitrogen), $1 \mu \mathrm{g}$ of random exanucleotide primers (Roche), and 40 units/tube M-MLV (Moloney murine leukemia virus) reverse transcriptase (Invitrogen, Italy). PCR was performed using $2 \mu \mathrm{l}$ of the cDNA prepared by the RT reaction in a final volume of $50 \mu \mathrm{l}$. The PCR reaction mixture contained $50 \mathrm{mM} \mathrm{KCl}, 20 \mathrm{mM}$ Tris- $\mathrm{HCl}(\mathrm{pH} 8.4$ at $\left.25^{\circ} \mathrm{C}\right), 1.5 \mathrm{mM} \mathrm{MgCl2}, 2.5$ units Taq polymerase (Platinum Taq, Invitrogen, Italy), $0.2 \mathrm{mM}$ each dNTP, and $0.2 \mu \mathrm{M}$ of each pair of primers. Primers for isoform-specific RUNX2 were 5'-(3021)ATGCTTCATTCGCCTCACAAAC-(3042)- $3^{\prime}$ and reverse 5'-(3432)-AGTCCCTCCTTTTTTTTTCAG(3412)-3'. Primers for osteocalcin were $5^{\prime}$-(17)-CATGAGAGCCCTCACACTCC-(37)-3' and $5^{\prime}-(321)-$ CTAGACCGGGCCGTAGAAGCG-(300)-3'. Primers for $\beta$-actin were $5^{\prime}$-(522)-CACACTGTGCCCATCTACGAGG-(543)- $3^{\prime}$ and $5^{\prime}$-(872)-AGTTTCGTGGATGCCACAGGA-(852)-3'. The numbers in brackets indicate the sequence positions of RUNX2 (GenBank AY090738), osteocalcin (GenBank NM_000711), and $\beta$-actin (GenBank X00351).

The predicted product sizes for the RUNX2, osteocalcin and $\beta$-actin primers are 412-bp (RUNX2 unspliced form), 304-bp, and 351-bp respectively. PCR was run in a thermal cycler (Hybaid) for 25-40 cycles, each cycle consisting of denaturation stage for $15 \mathrm{sec}$ at $94^{\circ} \mathrm{C}$, annealing for $20 \mathrm{sec}$ at $58^{\circ} \mathrm{C}$ for RUNX2 or $61^{\circ} \mathrm{C}$ for osteocalcin and actin primers respectively, and polymerization for $30 \mathrm{sec}$ at $72^{\circ} \mathrm{C}$. At the end of amplification, the PCR products were separated on a $2 \%$ agarose gel, stained in ethidium bromide, and photographed under ultraviolet light. To confirm the sizes of the fragments, a 100-bp DNA ladder (Invitrogen, Italy) was used as molecular weight marker. Actin was included as the control gene, which is expressed in 
all cells. The presence of 351-bp actin bands in all the PCR products confirms the similar conversion of RNA to cDNA in both control and bFGF treated samples.

\section{Osteocalcin and bFGF Secretion}

MG63 and TE85 osteosarcoma cell lines were maintained for $24 \mathrm{~h}$ in MEM $+0.5 \%$ FCS with or without bFGF $(20 \mathrm{ng} / \mathrm{ml})$. The cultures were then rinsed and maintained in serum-free medium for another $24 \mathrm{~h}$. Conditioned media (CM) from untreated or treated cultures were collected and centrifuged for $10 \mathrm{~min}$ at $3,000 \mathrm{rpm}$ in the presence of protease inhibitors (1 $\mathrm{mM}$ phenyl-methyl-sulfonyl-fluoride) to remove cells and debris. The osteocalcin and bFGF levels were determined in the CM of MG63 and TE85 osteosarcoma cell lines using specific ELISA kits (respectively Nuclear Laser Medicine, Milano and ICN Biomedicals, Milano) according to the manufacturer's instructions. Standard curve was run to determine osteocalcin and bFGF concentrations.

\section{GAG Synthesis and Identification}

Cells were maintained in vitro as above in the presence of $5 \mu \mathrm{Ci} / \mathrm{ml}$ of $\left[{ }^{3} \mathrm{H}\right]$-glucosamine hydrochloride (Amersham, specific activity $29 \mathrm{Ci} / \mathrm{mmol}$ ). Parallels coltures were added with bFGF antibody (R.D. System) at a concentration of $4.5 \mu \mathrm{g} / \mathrm{ml}$. At the end of the incubation time, cells and media were recovered separately and processed (22).

Aliquots of $\left[{ }^{3} \mathrm{H}\right]$-labelled GAG containing lysed cells and media were applied to a DE-52 cellulose anion exchange column $(0.7 \times 13 \mathrm{~cm})$, equilibrated with $10 \mathrm{mM}$ Tris- $\mathrm{HCl}(\mathrm{pH} 7.2)$, and eluted at room temperature with scaled-up concentrations of $\mathrm{NaCl}(0.3,0.4,0.5,0.6 \mathrm{M})$. One $\mathrm{ml}$ fractions were collected; $0.2 \mathrm{ml}$ aliquots were mixed with $10 \mathrm{ml}$ of Pico-Fluor 40 (Packard) and counted in the liquid scintillation counter. Recovery after the fractionation procedure was about 85-90 percent. Column fractions corresponding to specific types of GAG were pooled, dialysed, and lyophilised. Testicular hyaluronate lyase (beef, Miles Italiana S.p.A., Milano, Italy) and streptomyces hyaluronate lyase (Streptomyces hyaluroliticus, Seikagaku Kogyo Co., Tokyo) digestions were performed by dissolving lyophilised samples in $0.02 \mathrm{M}$ sodium acetate buffer, $\mathrm{pH} 5$, containing $0.1 \mathrm{M} \mathrm{NaCl}$, at $37^{\circ} \mathrm{C}$ for 24 hrs with 30 and 5 enzyme units respectively; chondroitin $\mathrm{ABC}$ lyase and chondroitin AC-II lyase (Arthrobacter aurescens, Seikagaku) digestions were performed in $0.01 \mathrm{M}$ Tris buffer, pH 8 at $25^{\circ} \mathrm{C}$ for $24 \mathrm{~h}$ with 0.5 and 0.01 enzyme units. Standard GAG (Sigma) were then added, precipitated with 3 vol of $5 \%$ potassium acetate in ethanol. Radioactivity was measured in both supernatants (digested GAG) and pellets (undigested GAG). Results are expressed as $\mathrm{cpm} / \mu \mathrm{g}$ DNA.

\section{RNA Extraction and Northern Blot Analysis}

Total cellular RNA was extracted from MG63 and TE85 osteosarcoma cell lines, cultured as above, by the single-step method (23). Twenty $\mu \mathrm{g}$ of total RNA were loaded per lane and electrophoresed on $1 \% \mathrm{w} / \mathrm{v}$ agarose gels containing $0.66 \mathrm{M}$ formaldehyde (24). Following electrophoresis, RNA was transferred onto nylon filters (Amersham, UK), and fixed by baking for $2 \mathrm{~h}$ at $80^{\circ} \mathrm{C}$. Nylon membranes were prehybridized for $2 \mathrm{~h}$ at $65^{\circ} \mathrm{C}$ in a solution containing $250 \mathrm{mM} \mathrm{Na} \mathrm{HPO}_{4}, 7 \%(\mathrm{w} / \mathrm{v})$ SDS, and $1 \mathrm{mM}$ EDTA. ${ }^{32} \mathrm{P}$-labeled cDNA probes were prepared as described below and hybridizations were carried out overnight at $65^{\circ} \mathrm{C}$ in the same solution. At the end of incubation, the filters were washed twice with $20 \mathrm{mM} \mathrm{Na} \mathrm{NPO}_{4}, 5 \%$ $(\mathrm{w} / \mathrm{v}) \mathrm{SDS}, 1 \mathrm{mM}$ EDTA at $65^{\circ} \mathrm{C}$, and once with the same solution containing only $1 \%(\mathrm{w} / \mathrm{v})$ SDS at $65^{\circ} \mathrm{C}$. The human cDNAs used as probes on Northern blots were a 1.6-kb human decorin (P2) cDNA and a 1.69-kb human biglycan (P16) cDNA, both kindly provided by Dr. Larry W. Fisher (25), of the NIDR, NIH, Bethesda, MD, USA; a 0.8-kb human bFGF cDNA, a generous gift of Dr. Judith Abraham, PhD, Scios Nova, CA, USA; a 0.67-kb cDNA for human procollagen $\alpha_{1}(\mathrm{I})$, (clone pHCALIU, a generous gift from Dr. Eero Vuorio, University of Turku, Finland), and a 0.7-kb cDNA for human syndecan-1 kindly donated by Dr. M. Bernfield, Newborn Medicine, Children's Hospital, Boston, MA, USA. For normalization purposes, the filters were stripped and rehybridized with a $1.3-\mathrm{kb}$ rat glyceraldehyde-3-phosphate dehydrogenase (pRGAPDH) cDNA. Probes were labeled with 5'$\left[\alpha^{32} \mathrm{P}\right] \mathrm{dCTP}$ (Amersham) by random priming (Amersham) and used to hybridize with Northern blots prepared as described above. For autoradiography, the membranes were exposed to preflashed Amersham Hyperfilm MP film at $-80^{\circ} \mathrm{C}$ with intensifying screens. $X$-ray films were developed and the labeled bands were quantified via laser scanning densitometry using Quanti-Scan software (Biosoft, UK) running on a Pentium II IBM desktop computer. The absolute counts were converted to relative densitometric units and corrected for the abundance of GAPDH mRNA.

\section{bFGF Binding Assay}

MG63 and TE85 osteosarcoma cell lines were incubated for $24 \mathrm{~h}$ in MEM plus $0.5 \%$ FCS, with and without bFGF at the dose of $20 \mathrm{ng} / \mathrm{ml}$. Basic FGF receptor binding was performed according to others (26). Briefly, the cells were incubated for $2 \mathrm{~h}$ at $37^{\circ} \mathrm{C}$ in serum free MEM with $0.15 \%$ gelatin before the start of each experiment. Cells were then washed twice with cold phosphate-buffered saline (PBS) and $200 \mu \mathrm{l}$ of cold MEM containing $25 \mathrm{mM}$ Hepes $\mathrm{pH} 7.5,0.15 \%$ gelatin and increasing concentration of ${ }^{125}$ I bFGF $(0.1-10 \mathrm{ng} / \mathrm{ml}$, Amersham Life Science 
Table 1. Alkaline phosphatase activity in MG63 and TE85 cells treated or not with bFGF.

\section{$\mu$ mol Paranitrophenolphosphate} (PNP) $/ \mathrm{min} / \mu$ g DNA

\begin{tabular}{lc}
\hline & MG 63 \\
Control & $0.12 \pm 0.01$ \\
bFGF & $0.11 \pm 0.01 \mathrm{NS}$ \\
& TE 85 \\
Control & $1.36 \pm 0.02 \S$ \\
bFGF & $1.13 \pm 0.04^{*}$ \\
\hline
\end{tabular}

Osteosarcoma cells were cultured for $24 \mathrm{~h}$ in MEM $+0.5 \%$ FCS in presence and in absence of bFGF $(20 \mathrm{ng} / \mathrm{ml})$. Alkaline phosphatase activity was measured as described in materials and methods. Values are expressed as mean \pm SD of five separate experiments, each in quadruplicate. Data were analysed by analysis of variance (ANOVA). Differences $v s$ each control: ${ }^{*}$ F-test significant at $99 \%$; NS = not significant. TE85 control vs MG63 control: $\S$ F-test significant at $99 \%$.

Products, England) were added to each well. The cells were incubated for $2 \mathrm{~h}$ a $4^{\circ} \mathrm{C}$ on an orbital shaker.

The binding medium was discarded and the cells were washed twice with ice cold PBS and twice with MEM/gelatin. To determine low affinity binding of bFGF, the cells were incubated twice for 5 min with cold PBS pH 7.5 containing $2 \mathrm{M} \mathrm{NaCl}$ and the cell extract was counted in a gamma counter (Packard). Control experiments were conducted using cells treated with heparinase to determine the reduced amount of low

Table 2. DNA content and cell number of MG63 and TE85 cells treated or not with bFGF.

\begin{tabular}{llll}
\hline & $\begin{array}{c}\mu \text { g DNA/ml of Cell } \\
\text { Homogenate }\end{array}$ & Cell Number $\times 10^{3}$ \\
& & MG 63 & \\
& & & $254 \pm 21$ \\
Control & $8.6 \pm 0.26$ & $234 \pm 29 \mathrm{NS}$ \\
bFGF & $8.4 \pm 0.41 \mathrm{NS}$ & & \\
& & TE 85 & \\
Control & $3.7 \pm 0.38 \S$ & & $159 \pm 13$ \\
bFGF & $4.5 \pm 0.09^{*}$ & & $198 \pm 15^{*}$ \\
& & & \\
\hline
\end{tabular}

Osteosarcoma cells were cultured for $24 \mathrm{~h}$ in MEM $+0.5 \%$ FCS with and without bFGF $(20 \mathrm{ng} / \mathrm{ml})$. DNA content and cell number were measured as described in materials and methods. Values are expressed as mean \pm SD of five separate experiments, each in quadruplicate. Data were analysed by analysis of variance (ANOVA). Differences $v s$ each control: * F-test significant at $95 \%$; NS $=$ not significant. TE85 control vs MG63 control: § F-test significant at $99 \%$. affinity receptor bound bFGF. Nonspecific binding was estimated in the presence of 100 fold excess of unlabeled recombinant human bFGF and subtracted from all data.

High affinity bound bFGF was determined by $20 \mathrm{mM}$ sodium acetate, $2 \mathrm{M} \mathrm{NaCl}$, pH 4.0 extraction. All experimental measurements were run in triplicate. Receptor binding was normalized with respect to cell number, and analyzed with Scatchard method.

\section{Statistical Analysis}

Results in the table and figures are the mean \pm SD of five separate experiments each performed in quadruplicate. Statistical analysis was performed by analysis of variance (ANOVA) followed by Sheffe F-test. The results from Northern blotting were obtained from five separate experiments and analysed by paired Student's $t$-test.

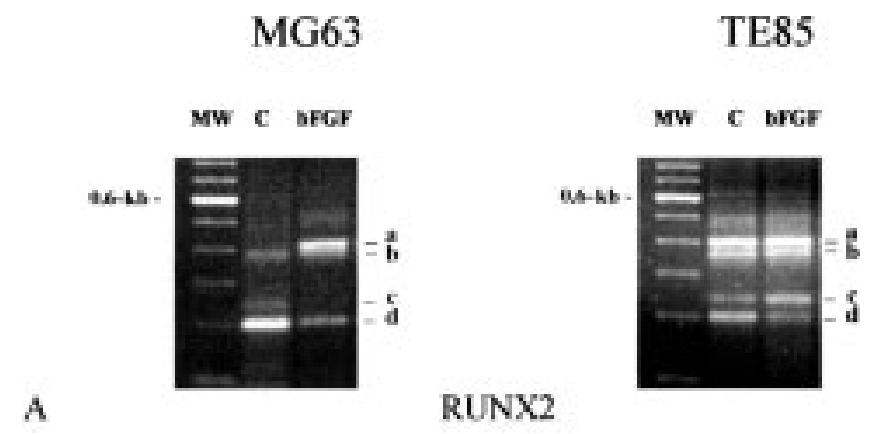

B
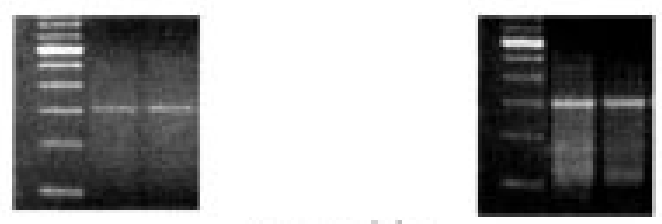

osteocalcin

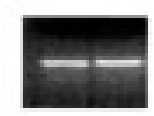

$\beta$-actin

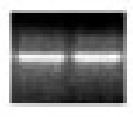

Fig. 1. RT PCR analysis of RUNX2 and osteocalcin mRNAs. MG63 and TE85 cells were untreated (control, C) or treated for $24 \mathrm{~h}$ with bFGF ( $20 \mathrm{ng} / \mathrm{ml})$. Total RNA was extracted and RT-PCR was performed using primers specific for RUNX2, osteocalcin, or $\beta$-actin used as internal standard. The first lane shows a 100-bp DNA ladder as molecular size marker (MW) with the brightest band corresponding to $0.6-\mathrm{kb}$. The a, $\mathrm{b}, \mathrm{c}$, and $\mathrm{d}$ bands represent forms of differentially spliced RUNX2 mRNAs. 


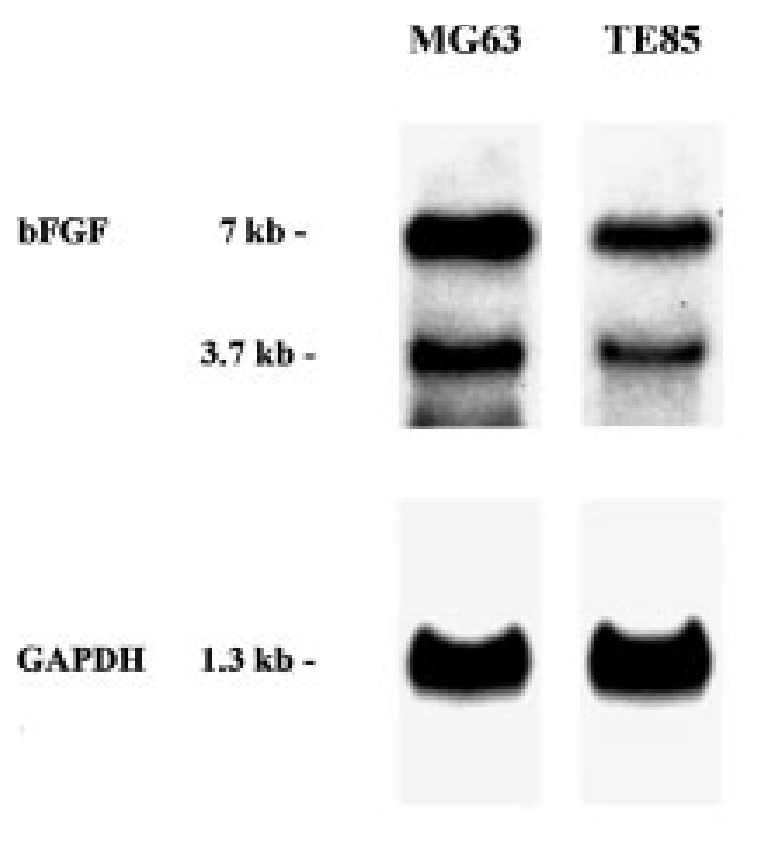

bFGF mRNA abundance

\section{MG63}

$1 \pm 0,12$

\section{TE85}

$0.34 \pm 0.05^{*}$
Fig. 2. Expression of bFGF and glyceraldehyde-3phosphate dehydrogenase (GAPDH) MRNA in MG63 and TE85 human osteosarcoma cell lines. Equal aliquots of total RNA per lane were analysed by Northern hybridization technique. The same filter was stripped and rehybridized with ${ }^{32} \mathrm{P}$-labelled cDNA probes as indicated. Autoradiograms are from a representative experiment. Messenger RNA levels, expressed as relative densitometric units $/ 20 \mu \mathrm{g}$ total RNA analysed/lane and corrected for the abundance of GAPDH mRNA. Mean \pm SD of five separate experiments. The results are analysed by paired Student's $t$ test. Difference $v s$ MG63 cell line: ${ }^{*} \mathrm{P}<0.001$.

\section{Results}

Alkaline Phosphatase Activity

Alkaline phosphatase activity (ALP) was markedly lower in MG63 cells than in TE85 (11.2-fold less) (Table 1). Basic FGF treatment inhibited by about $17 \%$ ALP activity only in the TE85 cells.

\section{Cell Growth}

Proliferation rate, as assessed by DNA assay and cell number, was greater in MG63 cells than in TE85 cells. Basic FGF significantly stimulated DNA synthesis and cell number only in TE85 cells (Table 2).

\section{Detection of RUNX2 and Osteocalcin by RT-PCR Analysis}

Figure 1A shows the steady state levels of RUNX2 mRNA species in the two osteosarcoma cell lines
Table 3. Osteocalcin and bFGF levels in conditioned media (CM) of MG63 and TE85 treated or not with bFGF.

\begin{tabular}{lcc}
\hline & $\begin{array}{c}\text { Osteocalcin } \\
\left(\mathbf{n g} / 10^{6} \text { Cells) }\right.\end{array}$ & bFGF (ng/10 ${ }^{6}$ Cells) \\
\hline & \multicolumn{3}{c}{ MG 63 } \\
& \multicolumn{2}{c}{$381.3 \pm 29.1$} \\
Control-CM & $141.9 \pm 15.9$ & $526.3 \pm 36.9^{*}$ \\
bFGF-CM & $109.1 \pm 10.6^{* *}$ & TE 85 \\
& $146 \pm 6.6 \S$ & $311 \pm 30$ \\
Control-CM & $85 \pm 3.4^{*}$ & $383 \pm 30.8^{*}$ \\
bFGF-CM & & \\
& & \\
\hline
\end{tabular}

Osteocalcin and bFGF levels in CM obtained from MG63 and TE85 osteosarcoma cell lines cultured for $24 \mathrm{~h}$ in MEM $+0.5 \%$ FCS (Control-CM) or treated with bFGF (20 ng/ml) (bFGF-CM), were quantified by ELISA as described in materials and methods. Values are expressed as mean \pm SD of five separate experiments each in quadruplicate. Data were analysed by analysis of variance (ANOVA). Difference $v s$ each control: *F-test significant at $99 \%$; **F-test significant at $95 \%$. §Difference vs MG63 control-CM not significant.

and the effects of bFGF. We used PCR primers detecting the human mRNA transcript that is translated to P1/MASNS protein isoform.

Bands $a, b, c$, and $d$ represent forms of differentially spliced RUNX2 mRNAs. Band $a$ shows the predicted unspliced 412-bp mRNA in which intron1 is completely retained, while band $b$ (about 380bp) could be a splice variant resulting from transcripts with a small internal deletion. Bands $c$ and $d$ are as predicted, based on two alternative splicing sites and the relative molecular weights are 246-bp and 212-bp respectively.

In untreated MG63 cells, PCR demonstrated one major 212-bp band and two faint bands (corresponding to alternatively spliced forms 246-bp and 380-bp). Basic FGF treatment markedly decreased the 212-bp band and gave origin to a larger band of 412-bp. In TE85 cells, the pattern of band amplification was more complex, because untreated and bFGF treated cells all showed the four different mRNA species (labeled: $a, b$, $c$ and $d$ ). Basic FGF treatment induced only slight modifications on relative $c$ and $d$ band intensities.

Osteocalcin mRNA was expressed in both MG63 and in TE85, irrespectively of whether they were treated or not with bFGF (Fig. 1B).

\section{bFGF Expression}

Basic FGF transcript was found in both osteosarcoma cell lines (7- and 3.7-kb bands) (Fig. 2), but MG63 expressed about three times more bFGF than TE85.

\section{Osteocalcin and bFGF Secretion}

No significant differences in the levels of osteocalcin secreted into the media were observed between 

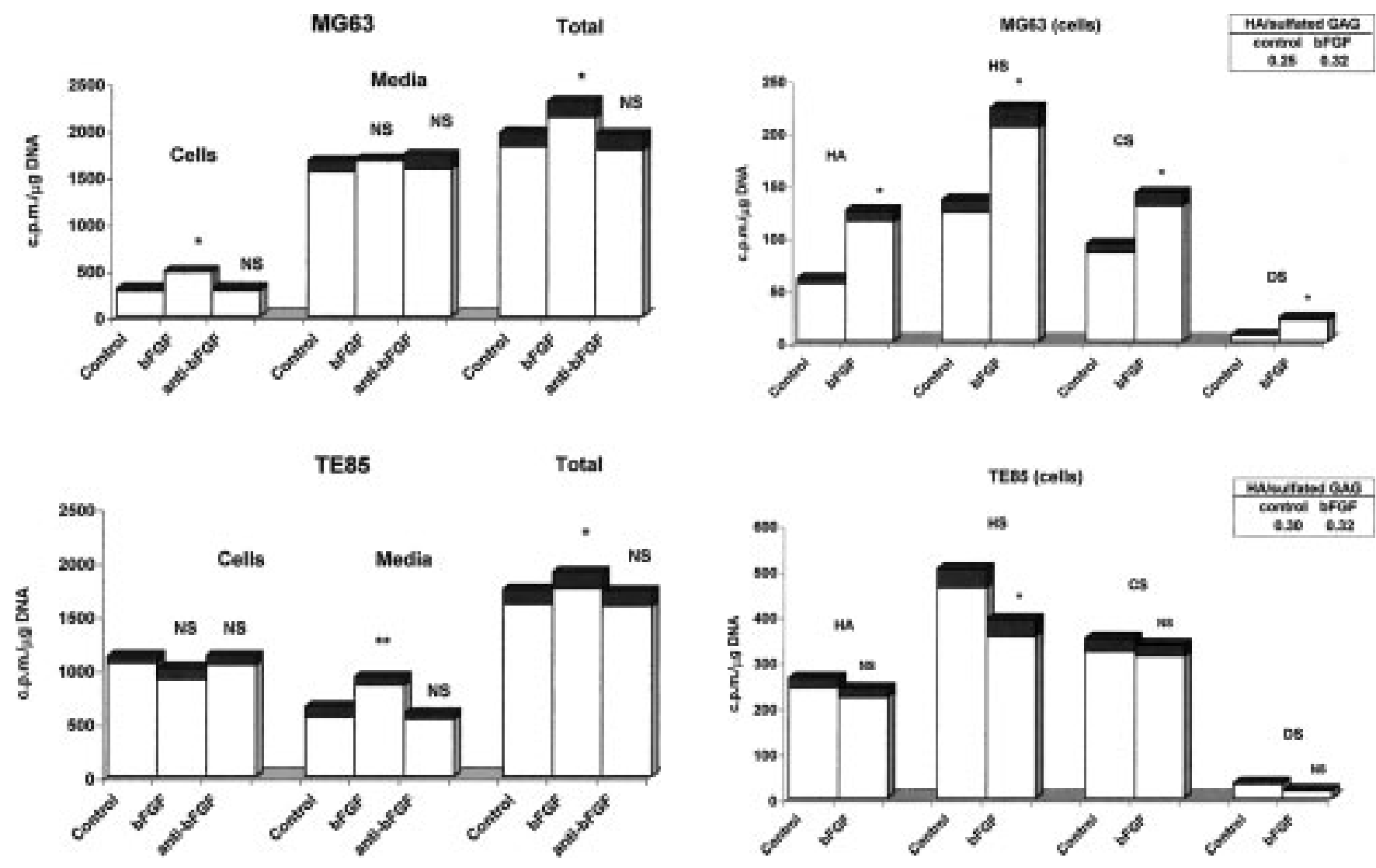

Fig. 3. $\left[{ }^{3} \mathrm{H}\right]$ glucosamine incorporation in GAG synthesized by MG63 and TE85 osteosarcoma cell lines treated or not with bFGF and anti-bFGF. Cells were maintained in MEM $+0.5 \%$ FCS for $24 \mathrm{~h}$ with or without bFGF $(20 \mathrm{ng} / \mathrm{ml})$ and anti-bFGF $(4.5 \mu \mathrm{g} / \mathrm{ml})$. Cells and media were processed as described in Materials and Methods. Values are expressed as $\mathrm{cpm} / \mu \mathrm{g}$ DNA and are the mean \pm SD of five separate experiments, each in quadruplicate. Data were analysed by analysis of variance (ANOVA). Differences $v s$ control: *F-test significant at $99 \%$; ${ }^{*}$ F-test significant at $95 \%$. NS $=$ not significant.

MG63 and TE85 cells (Table 3). Treatment with bFGF significantly decreased osteocalcin secretion in MG63 and TE $85 \mathrm{CM}$.

Basic FGF secretion was significantly greater in MG63 CM than in TE85 and markedly increased in both cell lines after bFGF was added, the increase being more evident in MG63 CM.

\section{GAG Synthesis}

MG63 cells synthesized slightly more total GAG $(+11.6 \%)$ than TE85 cells (Fig. 3). GAG secretion into the medium was greater in MG63, while GAG cellular accumulation was prevalent in TE85. Treatment with bFGF increased total GAG synthesis in both cell lines but the effects on secretion and cellular accumulation differed. In MG63, exogenous bFGF increased GAG accumulation into the cellular compartment by about $74 \%$ without significantly

Fig. 4. $\left[{ }^{3} \mathrm{H}\right]$ glucosamine incorporation into individual cellular GAG classes in MG63 and TE85 osteosarcoma cell lines treated or not with bFGF. Cells were maintained in MEM $+0.5 \%$ FCS for $24 \mathrm{~h}$ with or without bFGF $(20 \mathrm{ng} / \mathrm{ml})$ and $\left[{ }^{3} \mathrm{H}\right]$ glucosamine, lysed and aliquots of cell extracts were applied to DE-52 cellulose anion exchange column and processed as described in materials and methods. $\mathrm{HA}=$ hyaluronic acid; HS = heparan sulphate; CS = chondroitin-4 and -6 sulphate; DS $=$ dermatan sulphate. Values are expressed as cpm $/ \mu \mathrm{g}$ DNA and are the mean \pm SD of five separate experiments, each in quadruplicate. Data were analysed by analysis of variance (ANOVA). Differences $v s$ control: *F-test significant at $99 \%$. NS $=$ not significant.

influencing secretion into the medium. In TE85 cells, bFGF increased GAG secretion by about $54 \%$, but did not modify the GAG content in the cellular pool.

Chromatographic analyses of the cell lysates and culture media, mainly revealed four classes of GAG: hyaluronic acid (HA), heparan sulphate (HS), chondroitin sulphate (CS), and dermatan sulphate (DS) (Fig. 4). In the cell compartment, the HA/sulphated GAG ratio shifted in favour of sulphated GAG with HS as the main class of cellular GAG in both MG63 and TE85 cell lines. Basic FGF significantly increased the HA/sulphated GAG ratio only in MG63. MG63 secreted mainly HA GAG class and TE85 mainly CS (Fig. 5). The $\mathrm{HA} /$ sulphated GAG ratio shifted in favour of HA in MG63. In TE85 the ratio was, on the contrary, in 

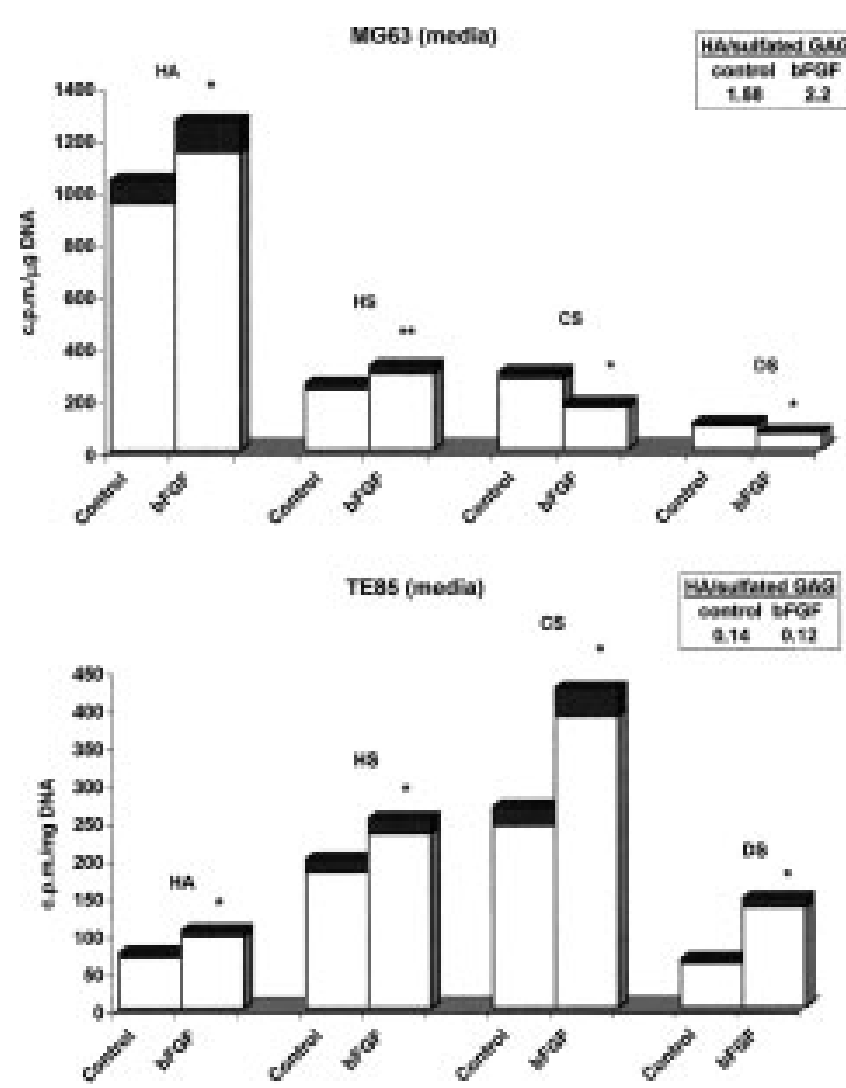

bistycan

$\operatorname{pre} \alpha_{1}(\mathbf{l})$

$5.8 \mathrm{~kb}-$

$4.7 \mathrm{~kb}$ -

Control BFGF

decorin

syndecan

$2.5 \mathrm{~kb}-$
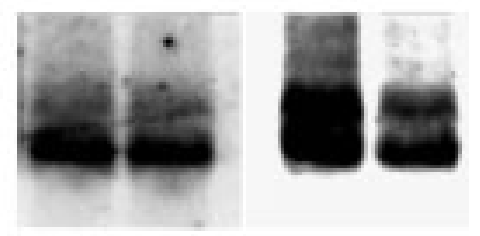

\section{$1.9 \mathrm{~kb}-$}

$1.6 \mathrm{~kb}$.

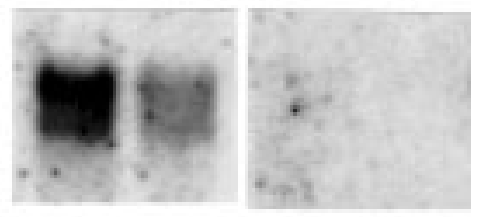

or

GAPDH

$1.3 \mathrm{~kb}$ -
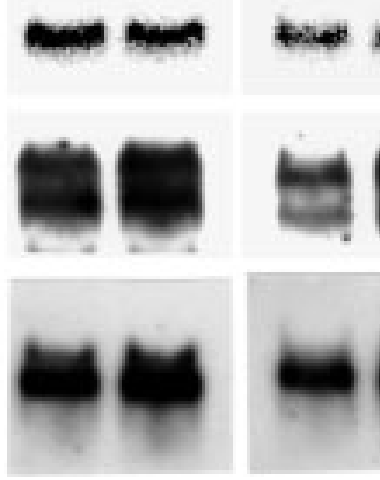

$3.4 \mathrm{~kb}$

Fig. 5. $\left[{ }^{3} \mathrm{H}\right]$ glucosamine incorporation into GAG classes secreted by MG63 and TE85 osteosarcoma cell lines treated or not with bFGF. Cells were maintained in MEM + $0.5 \%$ FCS for $24 \mathrm{~h}$ with or without bFGF $(20 \mathrm{ng} / \mathrm{ml})$ and $\left[{ }^{3} \mathrm{H}\right]$ glucosamine as described in materials and methods. Aliquots of media were applied to DE-52 cellulose anion exchange column and processed as described in materials and methods. $\mathrm{HA}=$ hyaluronic acid; $\mathrm{HS}=$ heparan sulphate; $\mathrm{CS}=$ chondroitin -4 and -6 sulphate; DS $=$ dermatan sulphate. Values are expressed as cpm/ $/ \mu \mathrm{g}$ DNA and are the mean \pm SD of five separate experiments, each in quadruplicate. Data were analysed by analysis of variance (ANOVA). Differences $v s$ control: *F-test significant at $99 \%$, ${ }^{* *}$ F-test significant at $95 \%$, NS $=$ not significant.

favour of sulphated GAG. In MG63, bFGF increased HA and reduced CS and DS levels; consequently the HA/sulphated GAG ratio was increased. In TE85, bFGF increased all unsulphated and sulphated GAG without influencing the HA/sulphated GAG ratio. The addition of bFGF antibody annulled the bFGF effects.

\section{Expression of mRNA Levels for Type I Procollagen and Proteoglycans}

Northern blots were performed to analyse the mRNA levels of type I procollagen and PG in the two osteosarcoma cell lines treated or not with bFGF (Fig. 6). GAPDH mRNA levels on the same Northern blots served as control. Similar levels of GAPDH mRNA in control and bFGF-treated cultures indicated the specific mRNA changes were not due to the variations in ribosomal or poly- $\mathrm{A}^{+}$

Fig. 6. Expression of type I procollagen, decorin, biglycan, syndecan, and glyceraldehyde-3-phosphate dehydrogenase (GAPDH) MRNA in MG63 and TE85 human osteosarcoma cell lines treated or not with bFGF. Equal aliquots of total RNA per lane were analysed by Northern hybridization technique. The same filter was stripped and rehybridized with ${ }^{32} \mathrm{P}$-labelled cDNA probes as indicated. Autoradiograms are from a representative experiment.

RNA fractions. The abundance of each specific mRNA relative to GAPDH mRNA was calculated by densitometric analysis of the Northern filters (Fig. 7). Both human osteosarcoma cells expressed $\alpha_{1}(\mathrm{I})$-procollagen mRNA (5.8- and 4.7-kb bands). TE85 cells produced about three times more $\alpha_{1}(\mathrm{I})$-procollagen mRNA than MG63 cells. Basic FGF reduced TE85 collagen expression by $57 \%$ but had no significant effects on $\alpha_{1}(\mathrm{I})$-procollagen mRNA in MG63 cells.

Under our experimental conditions decorin mRNA could be quantified only in MG63 cells. Basic FGF reduced decorin mRNA expression by $87 \%$. MG63 also expressed biglycan mRNA at higher level than TE85 cells (about 1.5-fold), but adding exogenous bFGF did not modify biglycan expression. Syndecan transcripts (of approximately 2.6 and $3.4 \mathrm{~kb}$ ) were about twice as high in MG63 cells as in TE85 cells. Treatment with bFGF increased the steady-state level of syndecan in MG63 by $48 \%$ and in TE 85 by $129 \%$. Adding bFGF antibody, blocked the bFGF effects. 

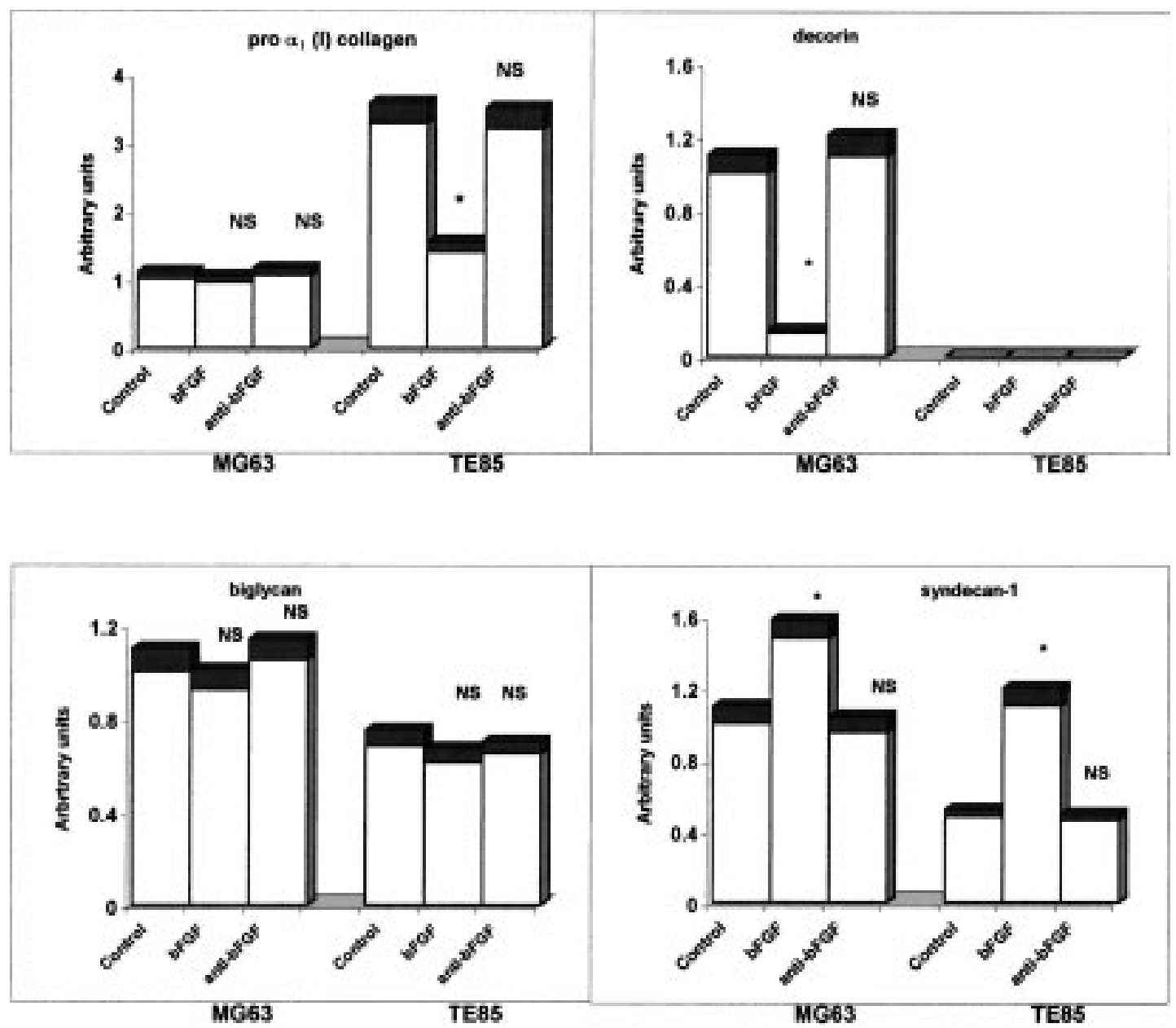

Fig. 7. Densitometric analysis of type I procollagen, decorin, biglycan, and syndecan-1 mRNA levels in human MG63 and TE85 osteosarcoma cell lines treated or not with bFGF and anti-bFGF. Labeled bands were quantitated by laser scanning densitometry. Data represent the mRNA levels, expressed as relative densitometric units/20 $\mu \mathrm{g}$ total RNA analysed/lane and corrected for the abundance of GAPDH mRNA (arbitrary units). All values are the mean \pm SD of five separate experiments. The results are analysed by paired Student's t-test. Differences $v$ s control: ${ }^{*} \mathrm{P}<0.01 ; \mathrm{NS}=$ not significant.

\section{bFGF Receptor Binding Assay}

Figures 8 and 9 illustrate the results of bFGF binding assays. MG63 cells expressed more bFGF receptors than TE85 cells. Low affinity receptors were $13009 \pm 1240$ vs. $7926 \pm 291$ and high affinity receptors were $3728 \pm 108$ vs. $1397 \pm 56$, respectively. Basic FGF treatment reduced the number of low and high affinity binding receptors in both cell lines.

\section{Discussion}

Dedifferentiation processes and unbalanced autocrine production of growth factors are known to be involved in the multistep progress of tumorigenesis. In the present study, we investigated the differentiation stage and the effects of bFGF in MG63 and TE85, two human osteosarcoma cell lines.

We demonstrated that the runt-related transcription factor-2 (RUNX2) mRNA, is differentially spliced in MG63 and TE85 cells. While TE85 ex- pressed all four different mRNA species related to PI/MASNS isoforms, MG63 showed one major band (221-bp) and two faint bands. The multiplicity of alternative splice variants in the RUNX2 gene suggest that all these different products could potentially have different biologic effects and the role of each form in regulating osteoblast differentiation remains to be defined.

Basic FGF influence the transcription of alternative spliced mRNA forms differently in the two cell lines. In MG63, in particular, bFGF induced a decrease of $212 \mathrm{bp}$ band and gave origin to two new larger bands. To our knowledge, this is the first indication that bFGF elicits a direct different splicing of RUNX2 in MG63 and TE85 human osteosarcoma cells. The result could be related to their different osteoblast maturation stages.

Furthermore, our results showed that under basal conditions, TE85 cells had a lower proliferation rate, higher levels of ALP activity, and higher 


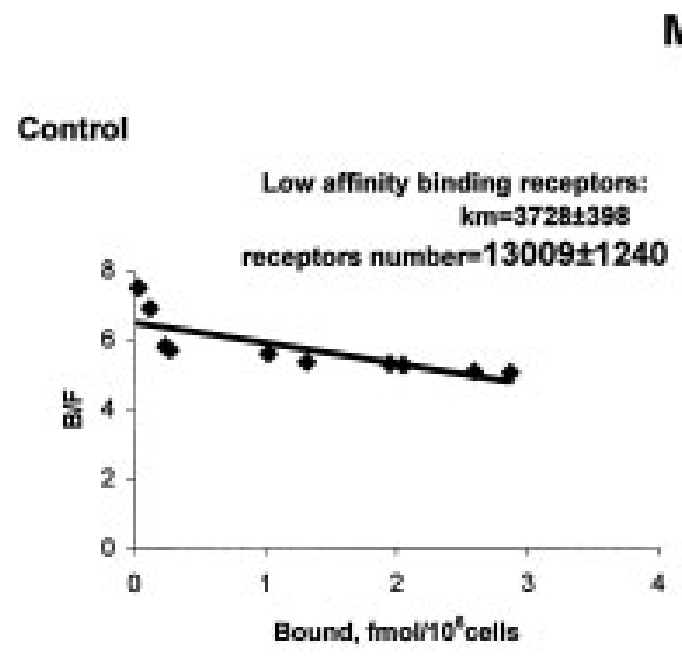

MG63
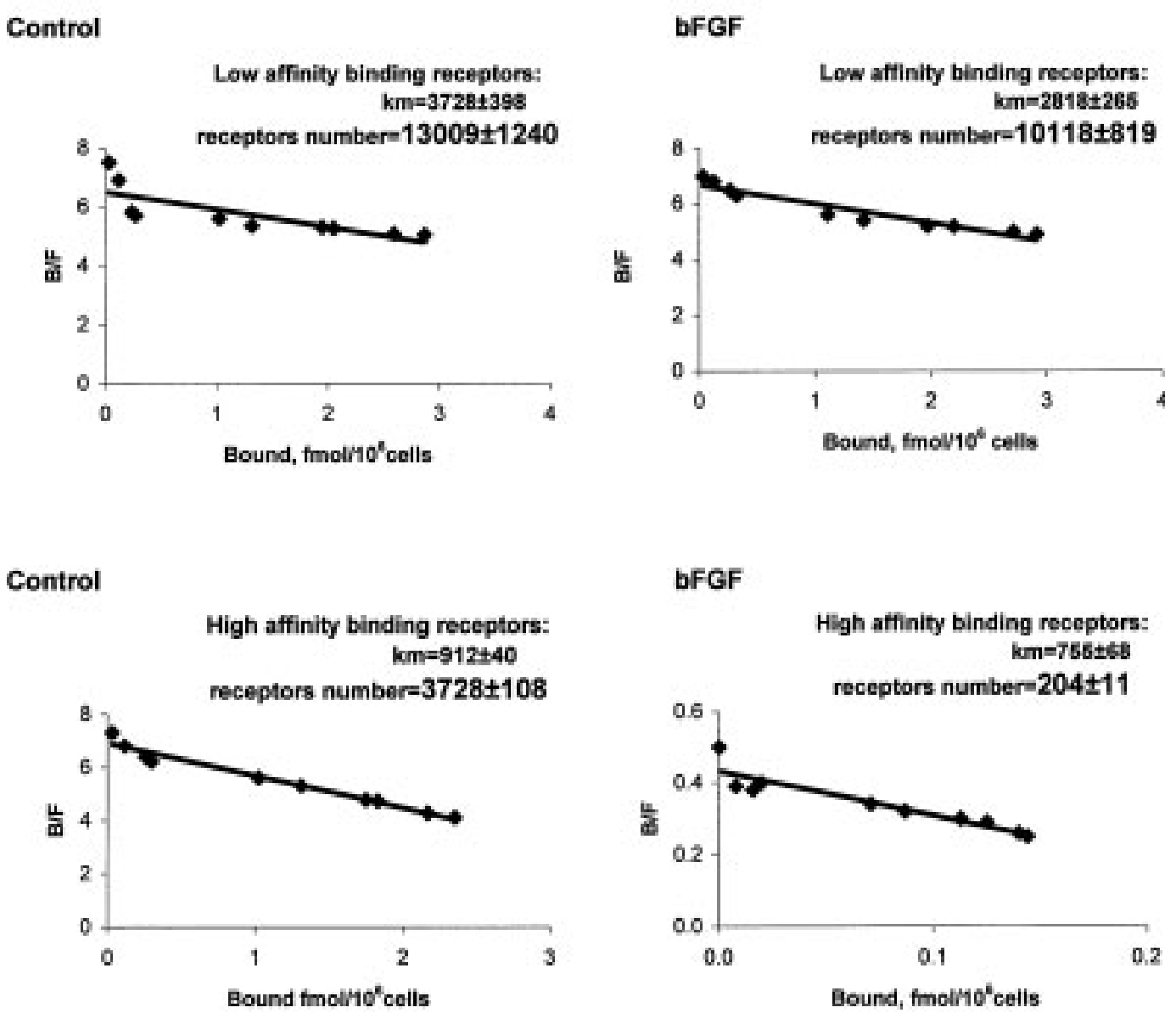

Fig. 8. Scatchard analysis of ${ }^{125}$ I-bFGF binding to MG-63 osteosarcoma cell lines treated or not with bFGF. The cells were preincubated at $37^{\circ} \mathrm{C}$ for $2 \mathrm{~h}$ in serum-free medium containing $0.15 \%$ gelatin, then incubated at $4^{\circ} \mathrm{C}$ for $2 \mathrm{~h}$ in serum-free medium containing different concentrations of bFGF. The medium was removed, and cells were washed with cold PBS. Lowaffinity binding was removed with PBS, pH 7.5, containing $2 \mathrm{M} \mathrm{NaCl}$. High-affinity binding was extracted using $20 \mathrm{mM}$ sodium acetate, $\mathrm{pH}$ 4. The cell-associated radioactivity was analyzed by the Scatchard procedure. Results are from a representative determination. The experiments were repeated three more times for each cell type with similar results.

procollagen I gene expression than the MG63, indicating that TE85 cells exhibit a more mature osteoblast phenotype. Basic FGF treatment, by promoting TE85 cell proliferation and down regulating its ALP activity, osteocalcin secretion and type collagen I gene expression, seems to decrease TE85 osteoblast differentiation. The down-regulation of procollagen I expression concurs with findings in human normal osteoblast cells (6) and in mouse osteoblast-like MC3T3-El cells (27).

Unlike the TE85 cells, GAG secretion in MG63 cells was higher than intra-cellular accumulation. It is interesting to note that MG63 cells secreted GAG that are, on the whole, richer in $\mathrm{HA}$, while TE85 cells secreted more sulphated GAG and more of the CS GAG class in particular. The higher quantity of sulphated GAG secreted into the medium by TE85 cells could account for their more mature, mineralizing phenotype, because CS GAG side chains are involved in bone matrix mineralization (28).

The response to bFGF was different in the two osteosarcoma cell lines. In MG63, bFGF increased only the cellular GAG, without influencing secretion. In TE85, it increased only the secreted quota without influencing total cellular GAG accumulation. Adding bFGF to MG63 cells reduced the absolute value of secreted CS content. On the contrary, mineralizing TE85 cells are stimulated by bFGF to secrete a quantitatively more abundant matrix.

In osteosarcoma cells, both decorin and biglycan contain hybrid polymers of chondroitin and dermatan sulphate chains (29-32). They regulate matrix assembly (33) and control cell adhesion (34), proliferation (35), and migration (36). Our findings on PG expression showed that decorin and biglycan $\mathrm{mR}$ NAs were expressed more in MG63 than in TE85 cells. The lack of decorin gene expression that we 


\section{TE 85}
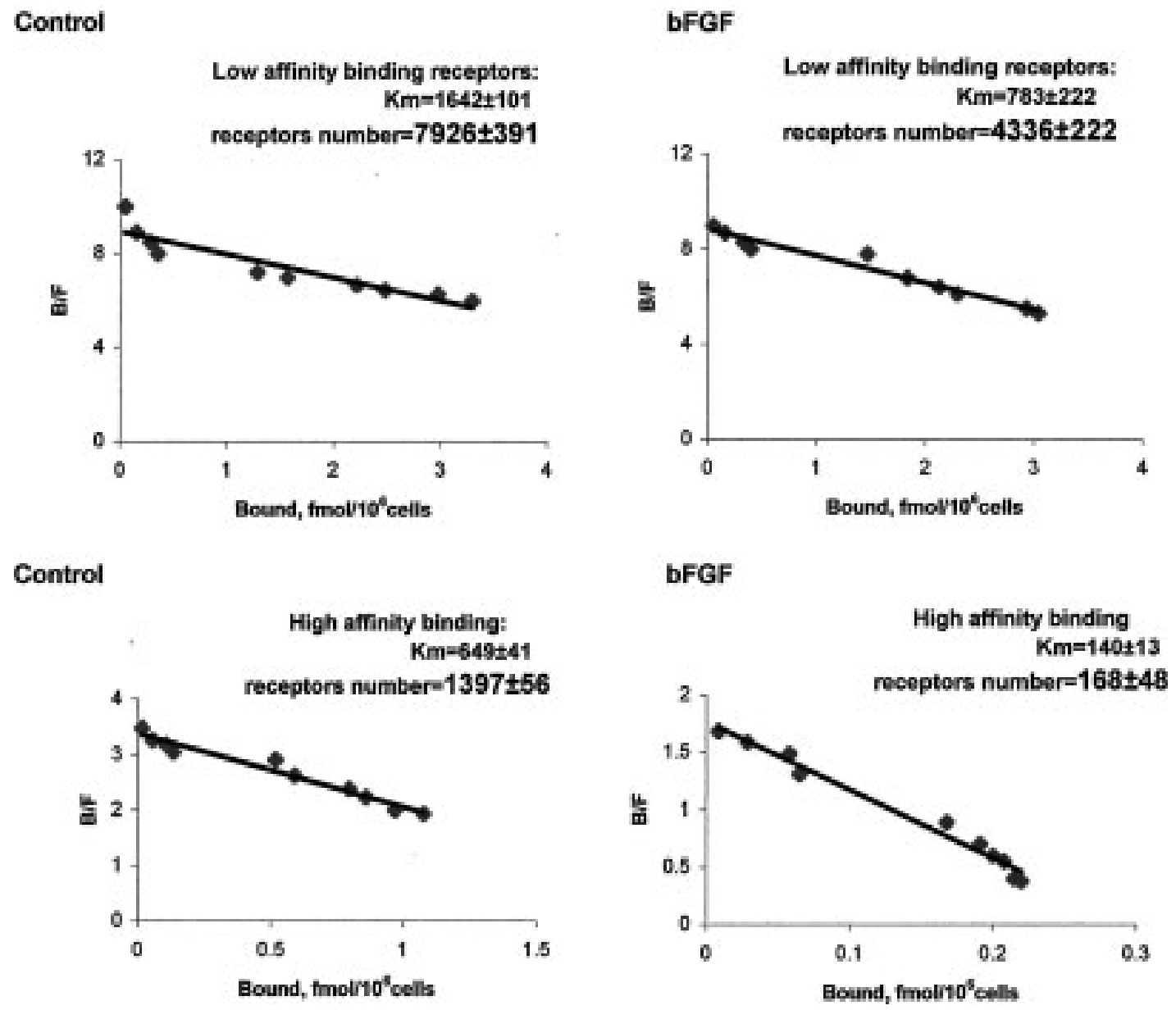

Fig. 9. Scatchard analysis of ${ }^{125}$ I-FGF2 binding to TE-85 osteosarcoma cell lines treated or not with bFGF. The cells were preincubated at $37^{\circ} \mathrm{C}$ for $2 \mathrm{~h}$ in serum-free medium containing $0.15 \%$ gelatin, then incubated at $4^{\circ} \mathrm{C}$ for $2 \mathrm{~h}$ in serum-free medium containing different concentrations of FGF2. The medium was removed, and cells were washed with cold PBS. Low-affinity binding was removed with PBS, pH 7.5, containing $2 \mathrm{M} \mathrm{NaCl}$. High-affinity binding was extracted using $20 \mathrm{mM}$ sodium acetate, $\mathrm{pH} 4$. The cell-associated radioactivity was analyzed by the Scatchard procedure. Results are from a representative determination. The experiments were repeated three more times for each cell type with similar results.

found in TE85 may account for their higher collagen expression. Indeed an inverse link between collagen amount and phenotypic expression of small PG genes has just been demonstrated in other in vitro models (37).

Only MG63 decorin expression was down regulated by bFGF confirming reports from other in vitro models (8). This finding can be explained in the light of our observation that bFGF reduces MG63 sulphated GAG secretion and leads to fewer CS and DS chains being available for the protein core binding which is necessary to produce a mature decorin PG expression (38).

MG63 also expressed more syndecan PG; bFGF increased the transcript in both osteosarcoma lines with the amount always being higher in MG63. Few data on the transcriptional regulation of syndecan by bFGF are available and only our group has investigated it in a human osteoblast model (8). As syndecan is considered a low affinity bFGF receptor which is able to affect bFGF binding to its high affinity receptor (39), different expression of syndecan levels might play a critical role in controlling bFGF receptor binding and in influencing its effects on osteosarcoma phenotypes. The results are confirmed by the bFGF binding assay that showed the absolute values of low and high affinity receptors were higher in MG63 than TE85. The enhanced bFGF-bFGF receptor binding, could increase the bFGF-dedifferentiative effects and account for the less mature osteoblast phenotype in MG63.

Furthermore, MG63 cells produced a higher level of bFGF message. The increase in bFGF mRNA paralleled the levels of bFGF detected in the media. Basic FGF over-expression in MG63 suggests an autocrine 
role of endogenous release in controlling the osteoblast phenotype. In support of this hypothesis in fact, bFGF, even without typical leader sequences, has been shown to be secreted by living and responsive cells (40-43). Our observation that exogenous bFGF modulates the phenotypic features exhibited by the two osteosarcoma cell lines and affects the osteoblast phenotype-related gene, RUNX2 and extracellular matrix production differently in each, may be considered direct evidence of the bFGF autocrine effect.

It is of interest that an autocrine loop involving the bFGF pathway may be implicated in the expression of different maturation stages, thus modulating tumour cell behaviour. As growth factor over expression has been reported in many neoplastic cell types (44-46), our findings support the view that osteosarcoma development involves several genetic alterations, one of which could be deregulation of autocrine bFGF growth and differentiation control. The ability to interfere with such an autocrine loop may represent an additional strategy for therapeutic intervention.

\section{Acknowledgments}

The work was supported by a grant from C.N.R., Ministero Università Ricerca Scientifica Tecnologica (M.I.U.R.) and Fondazione Cassa di Risparmio di Perugia (SA 172901 project). We are indebted to Dr. Larry W. Fisher (National Institutes of Health, Bethesda, MD, USA) for biglycan and decorin core protein cDNAs; to Dr. Judith Abraham, PhD (Scios Nova, CA, USA) for bFGF cDNA; to Dr. Eero Vuorio (University of Turku, Finland) for procollagen $\alpha_{1}$ (I) cDNA; to Dr. M. Bernfield (Newborn Medicine, Children's Hospital, Boston, MA, USA) for syndecan-1 cDNA.

We thank Dr. Geraldine Boyd for English language editing.

\section{References}

1. Franchi A, Arganini L, Baroni G, et al. (1998) Expression of transforming growth factor beta isoforms in osteosarcoma variants: Association of TGF beta 1 with high-grade osteosarcomas. J. Pathol. 185: 284-289.

2. Girnita L, Girnita A, Wang M, et al. (2000) A link between basic fibroblast growth factor (bFGF) and Fewing's sarcoma cells. Oncogene 31: 4298-4301.

3. Yamaguchi F, Saya H, Bruner JM, Morrison RS. (1994) Differential expression of two fibroblast growth factor-receptor genes is associated with malignant progression in human astrocytomas. Proc. Natl. Acad. Sci. USA 91: 484-488.

4. Mason IJ. (1994) The ins and outs of fibroblast growth factors. Cell 78: $547-552$.

5. Fedark NS, Termine JD, Young MF, Robey PG. (1990) Temporal regulation of hyaluronan and proteoglycan metabolism by human bone cells in vitro. J. Biol. Chem. 265: 12200-12209.

6. Bodo M, Carinci P, Venti G, et al. (1997) Glycosaminoglycan metabolism and cytokine release in normal and otosclerotic human bone cells interleukin-1 treated. Connect. Tissue Res. 36: 231-240.

7. Mundy GR, Bratter FC. (1995) Factors regulating bone resorbing and bone forming cells. In: Bone Remodelling and its Disorders. San Antonio: Martin Dunitz, 39-65.
8. Harbour ME, Gregory JW, Jenkins HR, Evans BA. (2000) Proliferative response of different human osteoblast like cell proinflammatory cytokines. Pediatr. Res. 48: 163-168.

9. Szebenyi G, Fallon JF. (1999) Fibroblast growth factors as multifunctional signaling factors. Intern. Review of Citology Acad. Press 185: 45-105.

10. Bodo M, Baroni T, Carinci F, et al. (2000) Interleukin secretion, proteoglycan and procollagen alpha (1)(I) gene expression in Crouzon fibroblasts treated with basic fibroblast growth factor. Cytokine 12: 1280-1283.

11. Wilkie AOM. (1997) Craniosynostosis: genes and mechanisms. Human Mol. Genet. 6: 1647-1656.

12. Bodo M, Baroni T, Carinci F, et al. (1999) A regulatory role of fibroblast growth factor in the expression of decorin, biglycan, betaglycan, and syndecan in osteoblasts from patients with Crouzon's syndrome. Eur. J. Cell Biol. 78: 323-330.

13. Carinci P, Becchetti E, Bodo M. (2000) Role of extracellular matrix and growth factors in skull morphogenesis and in pathogenesis of craniosynostosis. Int. J. Dev. Biol. 44: 715-723.

14. Clover J, Gowen M. (1994) Are MG-63 and HOS TE85 human osteosarcoma cell lines representative models of the osteoblastic phenotype? Bone 15: 585-591.

15. Bilbe G, Roberts E, Birch M, Evans DB. (1996) PCR phenotyping of cytokines, growth factors and their receptors and bone matrix proteins in human osteoblast-like cell lines. Bone 19: 437-445.

16. MacPherson H, Noble BS, Ralston SH. (1999) Expression and functional role of nitric oxide synthase isoforms in human osteoblast-like cells. Bone 24: 179-185.

17. Stewart M, Terry A, Hu M, et al. (1997) Proviral insertions induce the expression of bone-specific isoforms of PEBP2alphaA(CBFAl): evidence for a new myc collaborating oncogene. Proc. Natl. Acad. Sci. USA 94: 8646-8651.

18. Xiao ZS, Thomas R, Hinson TK, Quarles LD. (1998) Genomic structure and isoform expression of the mouse, rat and human Cbfa1/Osf2 transcription factor. Gene 214: 187-197.

19. Banerjee C, Javed A, Choi JY, et al. (2001) Differential regulation of the two principal Runx2/Cbfal n-terminal isoforms in response to bone morphogenetic protein-2 during development of the osteoblast phenotype. Endocrinology 142: 4026-4039.

20. Ibbotson KJ, Harrod J, Gowen M, et al. (1986) Human recombinant transforming growth factor alpha stimulates bone resorption and inhibits formation in vitro. Proc. Natl. Acad. Sci. USA 83: 2228-2232.

21. Labarca C, Paigen KA. (1980) Simple, rapid, and sensitive DNA assay procedure. Anal. Biochem. 102: 344-352.

22. Conrad GW, Hamilton C, Haynes E. (1977) Differences in glycosaminoglycans synthesized by fibroblast-like cells from chick cornea, heart, and skin. J. Biol. Chem. 252: 6861-6870.

23. Chomczynski P, Sacchi N. (1987) Single-step method of RNA isolation by acid guanidinium thiocyanate-phenol-chloroform extraction. Anal. Biochem. 162: 156-159.

24. Maniatis T, Fritsch EF, Sambrook J. (1982) Molecular Cloning: A Laboratory Manual, Cold Spring Harbor Laboratory, Cold Spring Harbor, NY.

25. Fisher LW, Termine JD, Young MF. (1989) Deduced protein sequence of bone small proteoglycan 1 (biglycan) shows homology with proteoglycan II (decorin) and several nonconnective tissue proteins in a variety of species. J. Biol. Chem. 264: 4571-4576.

26. Moscatelli D. (1987) High and low affinity binding sites for basic fibroblast growth factor on cultured cells: absence of a role for low affinity binding in the stimulation of plasminogen activator production by bovine capillary endothelial cells. J. Cell. Physiol. 131: 123-130.

27. Hurley MM, Abreu C, Harrison JR, et al. (1993) Basic fibroblast growth factor inhibits type I collagen gene expression in osteoblastic MC3T3-El cells. J. Biol. Chem. 268: 5588-5593.

28. Slater M, Patava J, Mason RS. (1994) Role of chondroitin sulfate glycosaminoglycans in mineralizing osteoblast-like cells: effects of hormonal manipulation. J. Bone Miner. Res. 9: 161-169. 
29. Hausser H, Schonherr E, Kresse H. (1993) Different galactosaminoglycan composition of small proteoglycans from osteosarcoma cells. Glycobiology 3: 557-562.

30. Kresse H, Hausser H, Schönherr E, Bittner K. (1994) Biosynthesis and interactions of small chondroitin/dermatan sulphate proteoglycans. Eur. J. Clin. Chem. Clin. Biochem. 32: 259-264.

31. Hocking AM, Shinomura T, McQuillan DJ. (1998) Leucinerich repeat glycoproteins of the extracellular matrix. Matrix Biol. 17: 1-19.

32. Schönherr E, Witsch-Prehm $P$, Harrach $B$, et al. (1995) Interaction of Biglycan with Type I Collagen. J. Biol. Chem. 270: 2776-2783.

33. Vogel KG, Paulsson M, Heinegard D. (1984) Specific inhibition of type I and type II collagen fibrillogenesis by the small proteoglycan of tendon. Biochem. J. 223: 587-597.

34. Merle B, Malaval L, Lawler J, et al. (1997) Decorin inhibits cell attachment to thrombospondin-1 by binding to a KKTR-dependent cell adhesive site present within the Nterminal domain of thrombospondin-1. J. Cell Biochem. 67: 75- 83.

35. Santra M, Mann DM, Mercer EW, et al. (1997) Ectopic expression of decorin protein core causes a generalized growth suppression in neoplastic cells of various histogenetic origin and requires endogenous p21, an inhibitor of cyclindependent kinases. J. Clin. Invest. 100: 149-157.

36. Merle B, Durussel L, Delmas PD, Clezardin P. (1999) Decorin inhibits cell migration through a process requiring its glycosaminoglycan side chain. J. Cell Biochem. 75: 538546.

37. Wegrowski Y, Gillery P, Kotlarz G, et al. (2000) Modulation of sulfated glycosaminoglycan and small proteoglycan synthesis by the extracellular matrix. Mol. Cell. Biochem. 205: 125-131.
38. Evangelisti R, Valeno V, Bosi G, et al. (1998) A contribution to the regulation of proteoglycan production: modulation by TGF $\alpha$, TGF $\beta$ and IL- 1 of glycosaminoglycan biosynthesis on $\beta$-D-xiloside in chick embryo fibroblasts. Conn. Tissue Res. 37: 77-85.

39. Yayon A, Klagsbrun M, Esko JD, et al. (1991) Cell Surface, heparin-like molecules are required for binding of basic fibroblast growth factor to its high affinity receptor. Cell 64: 841-848.

40. Mignatti P, Morimoto T, Rifkin DB. (1998) Basic fibroblast growth factor released by single, isolated cells stimulates their migration in an autocrine manner. Proc. Natl. Acad. Sci. USA 88: 11007-11011.

41. Mignatti P, Morimoto T, Rifkin DB. (1992) Basic fibroblast growth factor, a protein devoid of secretory signal sequence, is released by cells via s pathway independent of the endoplasmic reticulum-Golgi complex. J. Cell. Physiol. 151: 81-93.

42. Bashkin P, Neufeld G, Gitay-Goren H, Vlodavsky I. (1992) Release of cell surface-associated basic fibroblast growth factor by glycosylphosphatidylinositol-specific phospholipase C. J. Cell. Physiol. 151: 126-137.

43. Bodo M, Baroni T, Bellocchio S, et al. (2001) Bronchial epithelial cell matrix production in response to silica and basic fibroblast growth factor. Mol. Med. 7: 83-92

44. Benini S, Baldini N, Manara MC, et al. (1999) Redundancy of autocrine loops in human osteosarcoma cells. Int. J. Cancer 9: 581-588.

45. Slominski A, Wortsman J, Carlson A, et al. (1999) Molecular pathology of soft tissue and bone tumors. Arch. Pathol. Lab Med. 123: 1246-1259.

46. Sulzbacher I, Traxler M, Mosberger I, et al. (2000) Plateletderived growth factor-AA and alpha receptor expression suggest an autocrine and/or paracrine loop in osteosarcoma. Mod. Pathol. 13: 632-637. 